\title{
Fungos anemófilos em Porto Alegre, RS*
}

\author{
ADELINA MEZZARI
}

\section{Luiz Antonio Guerra Bernd (Orientador)}

Banca: Bruno Carlos Palombini (UFRGS), João Pedro Marques Pereira (FFFCMPA), Rogério Xavier (UFRGS)

O conhecimento dos fungos anemófilos em determinada cidade ou região é importante para o diagnóstico etiológico e o tratamento específico das manifestações alérgicas respiratórias. Várias técnicas quantitativas e qualitativas são preconizadas para coleta e identificação desses fungos na dependência do local estudado. Nesta pesquisa, sobre esporos de fungos do ar, foi utilizado o equipamento Rotorod Sampler®, que retira a amostra do ar através de um bastão de plástico preso a um motor elétrico que o faz girar rapidamente, sendo as partículas suspensas no ar recolhidas pelo bastão. As amostras foram coletadas uma vez por semana, durante 24 horas, correspondendo a um ciclo de coleta. Foram realizadas 52 coletas entre abril de 2000 e março de 2001. Os resultados mostraram prevalência de ascosporos (50,49\%), Cladosporium (17,86\%), Aspergillus/Penicillium (15,03\%), basidiosporos (3,84\%), rusts (3,82\%), Helminthosporium (2,49\%), Botrytis (1,22\%), Alternaria (1,19\%), smuts (0,90\%), Curvularia (0,87\%), Nigrospora (0,61\%) e Fusarium (0,08\%). Não foi possível identificar $1,59 \%$ dos esporos de fungos coletados no período. O maior número de esporos foi observado nos meses de verão e o menor, durante o outono. Utilizando provas in vivo e in vitro, avaliou-se a hipersensibilidade a fungos entre 39 pacientes atópicos sofrendo de rinite e ou asma brônquica. Os testes cutâneos identificaram sensibilização em 17,38\% dos pacientes, enquanto as provas sorológicas caracterizaram presença de IgE específica em 12,82\% dos casos avaliados. A detecção de significativo número de esporos de fungos no ar de Porto Alegre, com muitas espécies comprovadamente alergênicas, e os índices de sensibilização observados em indivíduos atópicos confirmam a importância do estudo dos fungos anemófilos nessa cidade, com vistas a aprimorar o diagnóstico e o manejo de pacientes com manifestações alérgicas respiratórias.

Descritores: fungos anemófilos, aeroalérgenos, sensibilização, asma, rinite.

Apresentada: 27 dezembro 2002

\footnotetext{
* Tese de doutorado nº 21 (Especialidade: Micologia). 91f. Programa de Pós-Graduação em Ciências Veterinárias da Faculdade de VeterináriaUFRGS, Porto Alegre/RS. CORRESPONDENCIA: A. Mezzari [amezzari@terra.com.br].
} 


\title{
Airborne fungi in Porto Alegre, $\mathbf{R S}^{* *}$
}

\author{
ADELINA MEZZARI
}

\author{
Luiz Antonio Guerra Bernd (Adviser)
}

Committee: Bruno Carlos Palombini (UFRGS), João Pedro Marques Pereira (FFFCMPA), Rogério Xavier (UFRGS)

Knowledge of airborne fungi in a given city or region is important for the ecological diagnosis and specific treatment of allergic manifestations induced by inhaled allergens. In order to diagnose the presence of airborne fungi, several qualitative and quantitative techniques are used depending on the study place. This study of fungal air spores was performed with a Rotorod Sampler ${ }^{\circledR}$, an equipment which samples the air through a plastic rod attached to an electric engine that makes it spin fast enough to collect the particles in the air. The samples were collected once a week for 24 hours using the standard cycle of the manufacturers. A total of 52 samples were obtained from April 2000 through March 2001. The results showed a prevalence of ascosporos (50.49\%), Cladosporium (17.86\%), Aspergillus/Penicillium (15.03\%), basidiosporos (3.84\%), rusts (3.82\%), Helminthosporium (2.49\%), Botrytis (1.22\%), Alternaria (1.19\%), smuts (0.90\%), Curvularia (0.87\%), Nigrospora (0.61\%), and Fusarium (0.08\%). Also, $1.59 \%$ of the spores detected here could not be identified by the systematic key used. More fungal spores were observed during the summer, and less during the autumn. Using in vivo and in vitro tests, the hypersensitivity to anemophilous fungi was assessed in 39 atopic individuals with rhinitis and asthma. The skin tests with airborne fungus allergens showed sensitivity in $17.94 \%$ of patients, while serum tests detected the presence of specific $\operatorname{IgE}$ in $12.82 \%$ of the cases. The occurrence of a great number of fungal spores as observed in this study, with many clearly allergenic species, emphasizes the importance of studying airborne fungus in our city in order to improve the diagnosis and care of patients with respiratory allergies.

Key words: airborne, allergens, sensitivity, asthma, rhinitis.

\footnotetext{
** Doctoral Dissertation no. 21 (Field: Mycology). 91p. Postgraduate Program in Veterinary Sciences, Faculdade de Veterinária, Universidade Federal do Rio Grande do Sul (UFRGS), Porto Alegre/Brazil. CORRESPONDENCE: A. Mezzari [amezzari@terra.com.br].
} 